\title{
Pengaruh Insentif, Motivasi dan Lingkungan Kerja Terhadap Kinerja Pegawai PT. Kaldu Sari Nabati Palembang
}

\author{
R.A. Rodia Fitri Indriani \\ Administrasi Bisnis, Politeknik Darussalam, radenrasyah@gmail.com
}

\begin{abstract}
This study aims to determine whether the variable incentives (X1), motivation (X2) and the Working Environment (X3) a significant influence on employee performance PT.Kaldu Sari Vegetable Palembang. Implementation of this study for 6 (six) months including the design, conduct and reporting of research results. This case study aims to determine the effect of Incentives, Motivation and Work Environment on Employee Performance PT.Kaldu Sari Vegetable Palembang either partially or jointly. Research population in question is the entire employee PT.Kaldu Sari Vegetable Palembang with a sample size of 50 people. The results were obtained regression coefficient Incentive (X1) of 0.002, Motivation (X2) is 0,021 and the Working Environment (X3) of 0.031 and also produces a constant value of 84.129. So that the multiple linear regression equation is as follows: $Y=$ $84.129+0,743 X 1+0,238 X 2+0,413 X 3$. While the results of correlation 0,544 , which means having a strong relationship between the independent variables and the dependent variable, also obtained by the coefficient of determination ( $R$ square) of 0,296. This value can be interpreted to mean that the percentage of influence Incentives, Motivation and Work Environment on Employee Performance was $29.6 \%$ while the remaining $70.4 \%$ is influenced by other variables not included in this study. Implementation is that the Chairman Plant Palembang PT.Kaldu Sari continuously improve Incentives, Motivation and Work Environment, so that the consciousness of themselves together to always strive to achieve the goals that have been set (Performance Officer Sari Vegetable PT.Kaldu Palembang).
\end{abstract}

Key Words: Correlation, Incentive, Motivation and Work Behavior

\begin{abstract}
ABSTRAK
Penelitian ini bertujuan untuk mengetahui apakah variabel Insentif $\left(X_{1}\right)$, Motivasi $\left(X_{2}\right)$ dan Lingkungan Kerja $\left(\mathrm{X}_{3}\right)$ pengaruh yang signifikan terhadap Kinerja Pegawai PT.Kaldu Sari Nabati Palembang. Pelaksanaan penelitian ini selama 6 (enam) bulan termasuk didalamnya merancang, melaksanakan dan melaporkan hasil penelitian. Penelitian studi kasus ini bertujuan untuk mengetahui pengaruh Insentif, Motivasi dan Lingkungan Kerja terhadap Kinerja Pegawai PT.Kaldu Sari Nabati Palembang baik secara parsial maupun secara bersama-sama. Dalam penelitian inipopulasi yang dimaksud adalah seluruh Pegawai PT.Kaldu Sari Nabati Palembang dengan jumlah sampel 50 orang. Dari hasil penelitian diperoleh koefisien regresi variabel Insentif $\left(X_{1}\right)$ sebesar 0,002 , Motivasi $\left(X_{2}\right)$ sebesar 0,021 dan Lingkungan Kerja $\left(X_{3}\right)$ sebesar 0,031 dan juga menghasilkan nilai konstanta sebesar 84,129. Sehingga persamaan Regresi Liniear Berganda adalah sebagai berikut : $Y=84,129+0,743 X_{1}+$ $0,238 X_{2}+0,413 X_{3}$. Sedangkan hasil korelasi 0,544 yang berarti mempunyai hubungan yang kuat antara variabel bebas dan variabel terikat, juga diperoleh koefisien determinasi ( $R$ square) sebesar 0,296 . Nilai ini dapat ditafsirkan bahwa besarnya persentase pengaruh Insentif, Motivasi dan Lingkungan Kerja terhadap Kinerja Pegawai adalah 29,6\% sedangkan selebihnya 70,4\% dipengaruhi oleh variabel lain yang tidak dimasukkan dalam penelitian ini. Implementasinya adalah agar pihak Pimpinan PT.Kaldu Sari Nabati Palembang secara terus menerus meningkatkan Insentif, Motivasi dan Lingkungan Kerja, sehingga dengan kesadaran diri mereka bersama-sama untuk selalu berusaha guna mencapai tujuan yang telah ditetapkan (Kinerja Pegawai PT.Kaldu Sari Nabati Palembang).
\end{abstract}

Kata Kunci: Pengaruh, Insentif, Motivasi dan Lingkungan Kerja 


\section{A. PENDAHULUAN}

Sumber daya manusia dapat mempengaruhi efisiensi dan efektivitas perusahaan, sekaligus merancang dan memproduksi barang dan jasa, mengawasi kwalitasnya, memasarkan produk, mengalokasikan sumber daya manusia yang ada, serta menentukan tujuan perusahaan. Peningkatan kualitas sumber daya manusia itu sendiri tak lepas dari pemberian insentif di perusahaan tersebut dimana untuk meningkatkan motivasi karyawan, Pemberian insentif di suatu perusahaan berperan penting dan sangat berpengaruh. Dengan adanya pemberian insentif diluar dari kompensasi/ salary akan berpengaruh terhadap motivasi dan lingkungan kerja karyawan maka kinerja sumber daya manusia yang diharapkan akan tercapai.

Kinerja adalah hasil kerja secara kualitas dan kuantitas yang dicapai oleh seorang pegawai dalam melaksanakan tugasnya sesuai dengan tanggung jawab yang diberikan kepadanya (Mangkunegara 2005 : 67). Selain itu kinerja juga dapat diartikan sebagai suatu hasil dari usaha seseorang yang dicapai dengan adanya kemampuan dan perbuatan dalam situasi tertentu. Sehingga kinerja tersebut merupakan hasil keterkaitan antara usaha, kemampuan dan persepsi tugas. Penurunan kinerja di PT.Kaldu Sari Nabati Palembang bisa terlihat pada omset penjualan sales di Tabel berikut :

Tabel Penjualan PT. Kaldu Sari Nabati Palembang

\begin{tabular}{|l|l|l|l|l|l|l|}
\hline No & \multicolumn{1}{|c|}{$\begin{array}{c}\text { Nama } \\
\text { Produk }\end{array}$} & \multicolumn{1}{|c|}{ April } & \multicolumn{1}{|c|}{ Mei } & \multicolumn{1}{c|}{ Juni } & Juli & \\
\hline 1. & $\begin{array}{l}\text { Richeese } \\
\text { Nabati } \\
\text { Cheese Wafer }\end{array}$ & 258.000 .000 & 244.650 .000 & 243.460 .000 & 243.269 .000 & 242.986 .000 \\
\hline 2. & $\begin{array}{l}\text { Richeese } \\
\text { Nabati Bisvit }\end{array}$ & 135.000 .000 & 134.700 .000 & 134.400 .000 & 134.278 .000 & 133.963 .000 \\
\hline 3. & $\begin{array}{l}\text { Richeese } \\
\text { Nabati } \\
\text { Sandwich }\end{array}$ & 128.540 .000 & 128.000 .000 & 127.640 .000 & 127.430 .000 & 127.189 .000 \\
\hline 4. & $\begin{array}{l}\text { Richeese Ahh' } \\
\text { Triple Cheese }\end{array}$ & 236.700 .000 & 232.400 .000 & 232.260 .000 & 231.975 .000 & 230.976 .000 \\
\hline 5. & $\begin{array}{l}\text { Richeese } \\
\text { Pasta Keju }\end{array}$ & 210.500 .000 & 209.450 .000 & 209.430 .000 & 209.180 .000 & 208.970 .000 \\
\hline 6. & $\begin{array}{l}\text { Richeese } \\
\text { Delis }\end{array}$ & 97.650 .000 & 97.197 .000 & 98.943 .000 & 98.520 .000 & 97.687 .000 \\
\hline 7. & $\begin{array}{l}\text { Richoco } \\
\text { Nabati } \\
\text { Chocolate } \\
\text { Wafer }\end{array}$ & 165.840 .000 & 164.750 .000 & 164.685 .000 & 164.600 .000 & 163.790 .000 \\
\hline 8. & $\begin{array}{l}\text { Richoco Bisvit } \\
\text { Selimut }\end{array}$ & 87.620 .000 & 87.430 .000 & 86.987 .000 & 86.880 .000 & 86.780 .000 \\
\hline 9. & $\begin{array}{l}\text { Richoco Siip } \\
\text { Chocochiz } \\
\text { Flavour }\end{array}$ & 134.960 .000 & 133.930 .000 & 134.150 .000 & 133.830 .000 & 133.670 .000 \\
\hline
\end{tabular}

Sumber : Data Penjualan April 2016- Agustus 2016

Pada PT. Kaldu Sari Nabati Palembang, peningkatan kinerja tentu saja tidak lepas dari faktor-faktor yang mempengaruhinya seperti pendidikan dan pelatihan, kompensasi, insentif, lingkungan kerja, gaya kepemimpinan, motivasi pegawai dan 
faktor-faktor lain yang diduga memiliki pengaruh kuat. Dalam faktor-faktor tersebut maka perlu dikaji insentif, motivasi dan lingkungan kerja pegawai serta pengaruhnya terhadap kinerja pegawai demi tercapainya tujuan perusahaan.

Bagi pegawai PT. Kaldu Sari Nabati Palembang, insentif adalah penting dalam rangka mencapai tujuan pegawai seperti karier dan kesejahteraan, sedangkan bagi organisasi/perusahaan, insentif merupakan salah satu instrument dalam pencapaian tujuan organisasi yang telah ditetapkan. Menurut Dessler (2007 : 102) pembayaran tunjangan kerja sebagai insentif adalah suatu kenaikan gaji yang diberikan kepada seorang pegawai berdasarkan kepada kinerjanya sendiri. Untuk itu penghargaan untuk menjembatani jurang antara tujuan organisasi dan harapan serta aspirasi bagi pegawai perlu diperhatikan oleh organisasi / perusahan lainnya. Pegawai akan memiliki motivasi kerja yang tinggi serta kinerja yang baik bila ia memiliki kepuasan kerja dan bersedia bekerja karena insentif yang kondusif serta mempunyai harapan. Dalam peningkatan kinerja karyawan selain insentif, faktor yang mempengaruhi juga adalah motivasi.

Menurut Hasibuan Malayu S.P dalam Sunyoto Danang (2012:191) motivasi adalah suatu perangsang keinginan daya gerak kemauan bekerja seseorang, setiap motif mempunyai tujuan tertentu yang ingin dicapai. Pemberian motivasi dengan tepat akan dapat menimbulkan semangat, gairah dan keikhlasan kerja dalam diri seseorang. Meningkatnya kegairahan dan kemauan untuk bekerja dengan sukarela tersebut akan menghasilkan pekerjaan yang lebih baik, sehingga akan meningkatkan produktivitas kerja. Sedangkan seseorang yang mempunyai motivasi kerja rendah, mereka akan bekerja seenaknya dan tidak berusaha untuk mendapatkan hasil yang maksimal. Selain Motivasi, Lingkungan Kerja juga mempengaruhi kinerja karyawan.

Lingkungan kerja dalam suatu perusahaan termasuk salah satu hal yang penting untuk diperhatikan. Meskipun lingkungan kerja tidak melaksanakan proses produksi dalam suatu perusahaan, namun lingkungan kerja mempunyai pengaruh langsung terhadap para karyawan yang melaksanakan proses produksi tersebut. Lingkungan kerja yang memusatkan bagi karyawannya dapat meningkatkan kinerja. Sebaliknya lingkungan kerja yang tidak memadai akan dapat menurunkan kinerja dan akhirnya menurunkan motivasi kerja karyawan. Alex S. Nitisemito (2000:183) mendefinisikan lingkungan kerja adalah segala sesuatu yang ada disekitar para pekerja yang dapat mempengaruhi dirinya dalam menjalankan tugastugas yang diembankan.

Lingkungan kerja yang baik yaitu apabila karyawan dapat melaksanakan kegiatan secara optimal, sehat, aman dan nyaman. Lingkungan kerja yang kurang baik dapat menuntut tenaga kerja serta waktu yang lebih banyak dan tidak mendukung diperolehnya rencangan sistem kerja yang efisien.

Fenomena yang terjadi pada PT. Kaldu Sari Nabati Palembang yang penulis amanati diantaraya Masih belum optimalnya pencapaian kinerja pegawai seperti pencapaian target yg belum optimal dan hasil kerja yang belum memenuhi standar. Pemberian Insentif terhadap para pegawai belum maksimal dan tidak tepat waktu dari manajemen PT. Kaldu Sari Nabati Palembang. Motivasi Kerja pegawai untuk meningkatkan kinerja dipandang masih rendah dan Lingkungan kerja di PT. Kaldu Sari Nabati Palembang belum sepenuhnya nyaman bagi pegawai. Seperti kurangnya ventilasi di dalam ruangan membuat penerangan menjadi kurang. Serta Belum optimalnya evaluasi kinerja yang diterapkan perusahaan dalam mempengaruhi kinerja pegawai seperti kurangnya kesadaran dan penghayatan terhadap tugas dan paraturan yang ada dan pengembangan karir pada pegawai PT. Kaldu Sari Nabati 
Palembang belum berjalan dengan baik, Pendidikan dan Pelatihan Karyawan belum sepenuhnya diberikan.

Tujuan Penelitian Berdasarkan rumusan masalah di atas, maka tujuan penelitian ini adalah untuk menganalisa, mengetahui dan membuktikan : a. Pengaruh Insentif, Motivasi, dan Lingkungan Kerja secara bersama-sama terhadap Kinerja Pegawai PT. Kaldu Sari Nabati Palembang. b. Pengaruh Insentif terhadap Kinerja Pegawai PT. Kaldu Sari Nabati Palembang. c. Pengaruh Motivasi terhadap Kinerja Pegawai PT. Kaldu Sari Nabati Palembang. d. Pengaruh Lingkungan Kerja terhadap Kinerja Pegawai PT. Kaldu Sari Nabati Palembang.

\section{B. KAJIAN TEORI}

\section{Pengertian Kinerja}

Kinerja merupakan hasil keseluruhan pekerjaan secara kuantitas maupun kualitas yang telah dilakukan seorang pegawai dalam mencapai apa yang menjadi tujuan suatu lembaga atau instansi. Lebih tegas lagi Lawlerand Poter menyatakan bahwa kinerja adalah "Succesful Role Achievement" yang diperoleh seseorang dari perbuatan-perbuatannya (Moh As'ad, 2003 : 260). Dari batasan Moh As'ad menyimpulkan bahwa kinerja adalah hasil yang dicapai seseorang menurut ukuran yang berlaku untuk pekerjaan bersangkutan. Variabel kinerja diukur atau dinilai dengan indikator kuantitas dan kualitas hasil kerja. Kinerja individu dalam sebuah organisasi akan berpengaruh terhadap prestasi organisasi. Oleh karena itu, kekompakan dalam sebuah organisasi akan berpengaruh pada pencapaian prestasi baik individu maupun organisasi. Tanpa kinerja yang baik disemua tingkat organisasi, pencapaian tujuan dan keberhasilan organisasi menjadi sesuatu yang sangat sulit untuk dicapai. Sehingga keberhasilan organisasi sebenarnya adalah prestasi para individu secara bersama, untuk itu dalam kaitannya prestasi perlu diketahui seberapa baik prestasi yang telah dicapainya.

\section{Pengertian Insentif}

Seorang pegawai selain mendapatkan gaji/upah, juga memperoleh tambahan penghasilan yang berupa insentif. Insentif adalah tambahan kompensasi di atas atau di luar gaji ataau upah yang diberikan oleh organisasi. Menurut Hasibuan (2000 : 117) "Insentif adalah tambahan balas jasa yang diberikan kepadakaryawan tertentu yang prestasinya diatas standar. Insentif ini merupakan alat yang dipergunakan pendukung prinsip adil dalam pemberian kompensasi". Tujuan pemberian insentif yaitu: 1. Insentif dapat dihitung dari jumlah nominal dengan criteria obyektif yang cenderung lebih diterima oleh para pegawai dibandingkan penghargaan prestasi yang dilakukan oleh atasan. 2. Insentif meningkatkan keyakinan pegawai bahwa prestasi yangtinggi akan menghasilkan imbalan insentif termasuk hal yang obyektif. 3. Insentif sebagai sarana motivasi yang mendorong para pegawai untuk bekerja dengan kemampuan yang optimal, yang dimaksudkan sebagai pendapatan ekstra diluargaji atau upah yang ditentukan.

Pemberian insentif dimaksudkan agar dapat memenuhi kebutuhan para pegawai dan keluarga mereka. Istilah sistem insentif pada umumnya digunakan untuk menggambarkan rencana-rencana pembayaran upah yang dikaitkan secara profitabilitas perusahaan. Menurut Dessler (2007 : 373) insentif yaitu programprogram yang mengkaitkan antara upah dan prestasi untuk memotivasi pegawai atau semua bentuk pembayaran yang diberikan kepada pegawai yang muncul dari pekerjaan mereka. 


\section{Pengertian Motivasi}

Motivasi kerja adalah pemberian kegairahan bekerja kepada para pegawai. Motivasi berasal dari kata movere yang berarti menggerakkan atau dorongan. Menurut Hasibuan Malayu S.P dalam Sunyoto Danang (2012:191) motivasi adalah suatu perangsang keinginan daya gerak kemauan bekerja seseorang, setiap motif mempunyai tujuan tertentu yang ingin dicapai. Pemberian motivasi dengan tepat akan dapat menimbulkan semangat, gairah dan keikhlasan kerja dalam diri seseorang. Meningkatnya kegairahan dan kemauan untuk bekerja dengan sukarela tersebut akan menghasilkan pekerjaan yang lebih baik, sehingga akan meningkatkan produktivitas kerja. Sedangkan seseorang yang mempunyai motivasi kerja rendah, mereka akan bekerja seenaknya dan tidak berusaha untuk mendapatkan hasil yang maksimal.

\section{Pengertian Lingkungan Kerja}

Alex S. Nitisemito (2000:183) mendefinisikan lingkungan kerja adalah segala sesuatu yang ada disekitar para pekerja yang dapat mempengaruhi dirinya dalam menjalankan tugas-tugas yang diembankan.

Lingkungan kerja adalah suatu lingkungan dimana karyawan bekerja, sedangkan kondisi kerja merupakan kondisi dimana karyawan tersebut bekerja. Dengan demikian, sebenarnya kondisi kerja termasuk salah satu unsur lingkungan kerja. Karena ruang kerja dapat mempengaruhi pekerja, terutama lingkungan kerja yang bersifat psikologis sedangkan pengaruh itu sendiri dapat bersifat positif dan dapat pula bersifat negatif.

\section{Kerangka Berfikir}

Insentif, Motivasi, Lingkungan Kerja menjadi semakin penting artinya karena peningkatan Insentif, Motivasi, dan Lingkungan Kerja merupakan upaya yang harus berlanjut terus menerus dan harus dilakukan terhadap seluruh lapisan pegawai. Dengan pengertian Insentif, Motivasi dan Lingkungan Kerja secara bersama-sama / simultan akan menentukan keberhasilan kinerja pegawai, maka dapat diharapkan tercapainya peningkatan kinerja pegawai yang ada giliranya dapat mewujudkan sumber daya manusia yang handal dalam mencapai tujuan yang ditetapkan oleh perusahaan. Dengan demikian Insentif, Motivasi dan Lingkungan Kerja secara berama-sama terhadap Kinerja.

\section{Hipotesis}

Berdasarkan kerangka pemikiran penelitian, teori dan kajian penelitian terdahulu maka dapat dirumuskan hipotesis sebagai berikut : 1. Diduga terdapat pengaruh Insentif, Motivasi, dan Lingkungan Kerja secara bersama-sama terhadap Kinerja Pegawai PT.Kaldu Sari Nabati Palembang 2. Diduga terdapat pengaruh Insentif terhadap Kinerja Pegawai PT. Kaldu Sari Nabati Palembang. 3. Diduga terdapat pengaruh Motivasi terhadap Kinerja pegawai PT.Kaldu Sari Nabati Palembang. 4. Diduga terdapat pengaruh Lingkungan Kerja terhadap Kinerja pegawai PT.Kaldu Sari Nabati Palembang.

\section{METODE PENELITIAN}

Penelitian ini akan dilaksanakan di PT. Kaldu Sari Nabati Palembang jalan Sukatani no 19 Palembang. Hal ini dikarenakan variabel-variabel yang akan diteliti ada hubungannya dengan kinerja pegawai PT. Kaldu Sari Nabati Palembang. Penelitian ini dirancang dengan menggunakan pendekatan deskriptif yang bersifat 
korelasional antara variabel bebas (independen Variabel) dengan variabel terikat (dependen Variabel). Penelitian ini menggunakan 3 variabel bebas dan 1 variabel terikat. Variabel bebas terdiri dari Insentif $\left(X_{1}\right)$, Motivasi $\left(X_{2}\right)$, dan Lingkungan Kerja $\left(\mathrm{X}_{3}\right)$ serta variabel terikatnya adalah Kinerja $(\mathrm{Y})$. Dalam penelitian ini menggunakan instrument penelitian berupa kuesioner, untuk mendapatkan data kuantitatif tentang variabel-variabel yaitu: Insentif, Motivasi, Lingkungan Kerja dan Kinerja akan menggunakan skala likert 1-5.

Kemudian data jawaban para responden diberi skor menggunakan system skala likert. Dalam hal ini ada 5 klasifikasi jawaban yang dibeerikan dengan kemungkinan pemberian skore atau nilai sebgai berikut: Jawaban SS (Sangat Setuju), Jawaban S (Setuju), Jawaban KS (Kurang Setuju), Jawaban TS (Tidak Setuju), Jawaban STS (Sangat Tidak Setuju).

Instrument disusun berdasarkan indikator-indikator dari variabel Insentif, Motivasi, Lingkungan Kerja dan Kinerja. Instrument dibuat berbentuk kuesioner dengan menggunakan skala Ordinal. Untuk menjamin agar data penelitian valid dan reliable, maka dilakukan uji validitas dan uji reabilitas.

1. Uji Validitas

Validitas adalah suatu derajat ketepatan/kelayakan instrumen yang digunakan untuk mengukur apa yang akan diukur (Zainal Ariffin.2012).

Dalam proses pengumpulan data, terlebih dahulu kuesioner yang akan dipakai harus diuji terlebih dahulu validitasnya yaitu untuk mengetahui keabsahan dari setiap butir pertanyaan dengan menggunakan alat uji korelasi product moment ( rhitung$)$, antara skor butir dan skor total menggunakan $\left(r_{\text {table }}\right)$ dengan tingkat $\alpha=$ 0,05 . Pengujian signifikan terhadap kriteria validitas setiap butir pertanyaan menggunakan program SPSS versi 17,0 dengan kriteria koefisien validitas dianggap signifikan jika harga rhitung $>\boldsymbol{r}$ table atau sig $(0,05)$.

2. Uji Reliabilitas

Menurut Sugiyono (2005) Reliabilitas adalah serangkaian pengukuran atau serangkaian alat ukur yang memiliki konsistensi bila pengukuran yang dilakukan dengan alat ukur itu dilakukan secara berulang.

Uji reliabilitas berjutuan untuk mengetahui kehandalan/kosistensi alat ukur bila dilakukan pengukuran kembali terhadap gejala yang sama melalui metode Alpha Cronbach Standard yang membandingakn $r$ hitung dengan Alpha Cronbach dimana $r$ hitung harus lebih besar dari 0,6. Dengan diperolehnya nilai hitung akan menunjukkan hasil indeks korelasi yang menyatakan ada tidaknya hubungan antara dua instrument atau lebih. Instrument disusun berdasarkan indikator-indikator dari variabel Insentif, Motivasi, Lingkungan Kerja dan Kinerja. Instrument dibuat berbentuk kuesioner dengan menggunakan skala Ordinal. Untuk menjamin agar data penelitian valid dan reliable, maka dilakukan uji validitas dan uji reabilitas.

Sesuai dengan variabel penelitian ini, terdapat dua jenis data yang dikumpulkan, yaitu data primer dan data sekunder. Data primer mencangkup 1) data tentang Insentif, 2) data tentang Motivasi, 3) data tentang Lingkungan Kerja, 4) data tentang Kinerja Karyawan. Pengumpulan data ini menggunakan teknik angket. Sedang data sekunder yaitu data pendukung penelitian dikumpulkan melalui studi dokumentasi, wawancara dan observasi. Data sekunder diperlukan dalam rangka melengkapi data primer yang tidak dapat diperoleh melalui angket.

Data primer yang dibutuhkan dari setiap karyawan ditampung pada instrument pengumpulan data, berupa kuesioner, dimana isinya diambil dari komponen diatas 
dengan skala pengukuran skala likert dengan option sebagai berikut : sangat setuju, setuju, kurang setuju, tidak setuju, sangat tidak setuju. Penskoran yang ditanyakan tergantung pada pertanyaan dan kuesioner. Untuk pertanyaan positif penskoran dimulai dari 5 sampai dengan 1. Sedangkan pertanyaan negative adalah nilai kebalikan dari penskoran dari pertanyaan positif, ini maksudnya untuk menghindari bias pada perhitungan. Pemilihan skor pada tiap-tiap pertanyaan juga dimaksudkan untuk mempermudah dalam perhitungan.

\section{HASIL DAN PEMBAHASAN}

Melihat hasil pengujian terhadap hipotesis yang diajukan, maka lebih jelas pengujian tersebut adalah sebagai berikut :

1. Hipotesis Pertama : Pengaruh Insenif, Motivasi dan Lingkungan Kerja secara simultan (bersama-sama) terhadap Kinerja Pegawai PT. Kaldu Sari Nabati Palembang.

Untuk menguji hipotesis Insenif, Motivasi dan Lingkungan Kerja secara simultan terhadap Kinerja Pegawai PT. Kaldu Sari Nabati Palembang dihitung dengan Uji F jika :

a. Ho : $b_{1}: b_{2}: b_{3}=0$, artinya tidak terdapat pengaruh Insentif $\left(X_{1}\right)$, Motivasi $\left(X_{2}\right)$ dan Lingkungan Kerja $\left(X_{3}\right)$ secara bersama-sama terhadap Kinerja Pegawai (Y) PT. Kaldu Sari Nabati Palembang.

b. Ho : $b_{1}: b_{2}: b_{3} \neq 0$, artinya terdapat pengaruh Insentif $\left(X_{1}\right)$, Motivasi $\left(X_{2}\right)$ dan Lingkungan Kerja $\left(\mathrm{X}_{3}\right)$ secara bersama-sama terhadap Kinerja Pegawai $(\mathrm{Y})$ PT. Kaldu Sari Nabati Palembang.

c. Level of Significance $95 \%(\alpha=0,05)$

d. Kriteria Pengujian :

- Terima Ho, jika sig. $F \geq 0,05$

- Tolak Ho, jika sig. $F<0,05$

\section{Tabel Uji-F ( Uji Simultan )}

\begin{tabular}{|c|c|c|c|c|c|c|}
\hline \multicolumn{7}{|c|}{ ANOVA $^{b}$} \\
\hline Model & & Sum of Squares & Df & Mean Square & $\mathrm{F}$ & Sig. \\
\hline \multirow[t]{3}{*}{1} & Regression & 397.797 & 3 & 132.599 & 6.452 & $.001^{a}$ \\
\hline & Residual & 945.423 & 46 & 20.553 & & \\
\hline & Total & 1343.220 & 49 & & & \\
\hline
\end{tabular}

\section{Sumber : Hasil Pengolahan Data SPSS}

Berdasarkan tabel diatas terlihat bahwa $\mathrm{F}$ hitung variabel Insentif, Motivasi dan Lingkungan Kerja secara simultan terhadap Kinerja Pegawai dengan nilai Sig. $\boldsymbol{F}$ didapat nilainya $0,001<\alpha=0,05$ berarti pada tingkat keyakinan $95 \% \mathrm{H}_{0}$ ditolak atau Variabel Insentif, Motivasi dan Lingkungan Kerja secara simultan berpengaruh sangat nyata terhadap Kinerja Pegawai. Dengan demikian, dapat dikatakan bahwa 
hipotesis pertama diterima. Dengan kata lain, makin baik Insentif, Motivasi dan Lingkungan Kerja yang diterapkan para pegawai PT. Kaldu Sari Nabati Palembang maka makin tinggi pula Kinerja Pegawai yang dihasilkan oleh para pegawai tersebut. Sebaliknya semakin buruk Insentif, Motivasi dan Lingkungan Kerja yang diterapkan para pegawai tersebut maka makin rendah pula Kinerja Pegawai yang diperlihatkan oleh pegawai tersebut. Kesimpulan Hipotesis pertama adalah benar adanya, yaitu terdapat pengaruh positif dan signifikan Insentif, Motivasi danLingkungan Kerja secara bersama-sama terhadap Kinerja Pegawai PT. Kaldu Sari Nabati Palembang.

2. Hipotesis Kedua : Pengaruh Insentif terhadap Kinerja Pegawai PT. Kaldu Sari Nabati Palembang

Hipotesis yang akan diuji secara statistik dalam penelitian adalah :

a. Ho : $b_{1}=0$, artinya tidak terdapat pengaruh Insentif $\left(X_{1}\right)$ terhadap Kinerja Pegawai (Y) PT. Kaldu Sari Nabati Palembang.

b. Ho : $b_{1} \neq 0$, artinya terdapat pengaruh Insentif $\left(X_{1}\right)$ terhadap Kinerja Pegawai (Y) PT. Kaldu Sari Nabati Palembang.

c. Level of Significance 95\% $(\alpha=0,05)$

d. Kriteria Pengujian :

- Terima Ho, jika sig. $F \geq 0,05$

- Tolak Ho, jika sig. $F<0,05$

Berdasarkan nilai t hitung dari tabel 29 Sig. $t$ didapat nilainya sebesar $0.002<\alpha$ $=0,050$ berarti pada tingkat keyakinan $95 \% \mathrm{H}_{0}$ ditolak atau Variabel Insentif secara parsial berpengaruh terhadap Kinerja Pegawai. Dengan demikian dapat dikatakan bahwa hipotesis kedua diterima. Dengan kata lain, makin tinggi Insentif pegawai PT. Kaldu Sari Nabati Palembang, maka makin tinggi pula Kinerja Pegawai yang dihasilkan oleh para pegawai tersebut. Sebaliknya, makin rendah Insentif maka makin rendah pula Kinerja Pegawai yang diperlihatkan oleh para pegawai. Kesimpulan Hipotesis kedua adalah benar adanya, yaitu terdapat pengaruh yang signifikan dan positif Insentif terhadap Kinerja pegawai PT. Kaldu Sari Nabati Palembang.

3. Hipotesis Ketiga : Pengaruh Motivasi terhadap Kinerja Pegawai PT. Kaldu Sari Nabati Palembang

Hipotesis yang akan diuji secara statistik dalam penelitian adalah :

a. Ho : $b_{2}=0$, artinya tidak terdapat pengaruh Motivasi $\left(X_{2}\right)$ terhadap Kinerja Pegawai (Y) PT. Kaldu Sari Nabati Palembang.

b. Ho : $b_{2} \neq 0$, artinya terdapat pengaruh Motivasi $\left(\mathrm{X}_{2}\right)$ terhadap Kinerja Pegawai (Y) PT. Kaldu Sari Nabati Palembang.

c. Level of Significance $95 \%(\alpha=0,05)$

d. Kriteria Pengujian :

- Terima Ho, jika sig. $F \geq 0,05$

- Tolak Ho, jika sig. $F<0,05$

Berdasarkan nilai t hitung dari tabel 29 Sig. $t$ didapat nilainya sebesar $0.021<\alpha$ $=0,050$ berarti pada tingkat keyakinan $95 \% \mathrm{H}_{0}$ ditolak atau Variabel Motivasi secara parsial berpengaruh terhadap Kinerja Pegawai. Dengan demikian dapat dikatakan bahwa hipotesis kedua diterima. Dengan kata lain, makin tinggi Motivasi pegawai PT. Kaldu Sari Nabati Palembang, maka makin tinggi pula Kinerja Pegawai yang 
dihasilkan oleh para pegawai tersebut. Sebaliknya, makin rendah Motivasi maka makin rendah pula Kinerja Pegawai yang diperlihatkan oleh para pegawai.

Kesimpulan: Hipotesis ketiga adalah benar adanya, yaitu terdapat pengaruh yang signifikan dan positif Motivasi terhadap Kinerja pegawai PT. Kaldu Sari Nabati Palembang.

4. Hipotesis Keempat : Pengaruh Lingkungan Kerja terhadap Kinerja Pegawai PT. Kaldu Sari Nabati Palembang

Hipotesis yang akan diuji secara statistik dalam penelitian adalah :

a. Ho : $b_{3}=0$, artinya tidak terdapat pengaruh Lingkungan Kerja $\left(X_{3}\right)$ terhadap Kinerja Pegawai (Y) PT. Kaldu Sari Nabati Palembang.

b. Ho : $b_{3} \neq 0$, artinya terdapat pengaruh Lingkungan Kerja $\left(\mathrm{X}_{3}\right)$ terhadap Kinerja Pegawai (Y) PT. Kaldu Sari Nabati Palembang.

c. Level of Significance $95 \%(\alpha=0,05)$

d. Kriteria Pengujian :

- Terima Ho, jika sig. $F \geq 0,05$

- Tolak Ho, jika sig. $F<0,05$

Berdasarkan nilai t hitung dari tabel 29 Sig. $t$ didapat nilainya sebesar $0.031<\alpha$ $=0,050$ berarti pada tingkat keyakinan $95 \% \mathrm{H}_{0}$ ditolak atau Variabel Lingkungan Kerja secara parsial berpengaruh terhadap Kinerja Pegawai. Dengan demikian dapat dikatakan bahwa hipotesis kedua diterima. Dengan kata lain, makin tinggi Lingkungan Kerja pegawai PT. Kaldu Sari Nabati Palembang, maka makin tinggi pula Kinerja Pegawai yang dihasilkan oleh para pegawai tersebut.

Sebaliknya, makin rendah Lingkungan Kerja maka makin rendah pula Kinerja Pegawai yang diperlihatkan oleh para pegawai. Kesimpulan Hipotesis keempat adalah benar adanya, yaitu terdapat pengaruh yang signifikan dan positif Lingkungan Kerja terhadap Kinerja pegawai PT. Kaldu Sari Nabati Palembang.

Hasil analisa statistik yang dilakukan dengan bantuan komputer meliputi Analisis Regresi, Analisis Korelasi, dan Koefisien Determinasi serta prediksi yang menunjukkan hal-hal sebagai berikut :

1. Hasil perhitungan menunjukkan bahwa koefisien regresi untuk variabel Insentif $\left(X_{1}\right)=0.743$, Motivasi $\left(X_{2}\right)=0.238$, Lingkungan Kerja $\left(X_{3}\right)=0.413$ dan juga menghasilkan nilai konstanta sebesar 84,129 Hasil perhitungan tersebut dapat diinterpretasikan sebagai berikut :

- Konstanta sebesar 84,129 menyatakan bahwa jika tidak ada peningkatan Insentif (X1), Motivasi (X2), Lingkungan Kerja (X3) maka Kinerja Pegawai (Y) PT. Kaldu Sari Nabati Palembang tetap sebesar 84,129 unit skor. Hal ini bisa dipahami karena masih ada variabel lain yang belum dimasukkan dalam penelitian ini , seperti Gaji, kompensasi, evaluasi kepuasan kerja, pengembangan karir, pendidikan dan pelatihan Pegawai yang tidak dimasukkan dalam penelitian ini.

- Dengan melihat besarnya koefisien regresi bahwa variabel Insentif $\left(X_{1}\right)$ 0.743 atau sama dengan $74,3 \%$ Artinya kecendrungan proyeksi perubahan antara variabel Insentif $\left(\mathrm{X}_{1}\right)$ dengan variabel Kinerja Pegawai $(\mathrm{Y})$ PT. Kaldu Sari Nabati Palembang menunjukkan bahwa setiap perubahan atau peningkatan variabel Insentif sebesar 100\% maka mengakibatkan 
perubahan atau peningkatan Kinerja Pegawai 74,3\% dengan tingkat signifikansi sebesar 5 persen $(\alpha=0,05)$.

- Koefisien regresi variabel Motivasi $\left(X_{2}\right) 0.238$ atau sama dengan $23,8 \%$ Artinya kecendrungan proyeksi perubahan antara variabel Motivasi $\left(\mathrm{X}_{2}\right)$ terhadap variabel Kinerja Pegawai (Y) PT. Kaldu Sari Nabati Palembang menunjukkan bahwa setiap perubahan atau peningkatan variabel Motivasi $\left(\mathrm{X}_{2}\right)$ sebesar $100 \%$ maka mengakibatkan perubahan atau peningkatan Kinerja Pegawai $(Y)$ sebesar $23,8 \%$ dengan tingkat signifikansi sebesar 5 persen $(\alpha=0,05)$.

- Koefisien regresi variabel Ligkungan Kerja $\left(X_{3}\right) 0.413$ atau sama dengan $43,1 \%$ Artinya kecendrungan proyeksi perubahan antara variabel Lingkungan Kerja $\left(\mathrm{X}_{3}\right)$ terhadap variabel Kinerja Pegawai (Y) PT. Kaldu Sari Nabati Palembang menunjukkan bahwa setiap perubahan atau peningkatan variabel Lingkungan Kerja $\left(X_{3}\right)$ sebesar 100\% maka mengakibatkan perubahan atau peningkatan Kinerja Pegawai 43,1\% dengan tingkat signifikansi sebesar 5 persen $(\alpha=0,05)$.

2. Ketiga variabel bebas tersebut variabel Insentif $\left(X_{1}\right)$, Motivasi $\left(X_{2}\right)$ dan Lingkungan Kerja $\left(\mathrm{X}_{3}\right)$ mempunyai korelasi yang kuat dan positif terhadap Kinerja Pegawai PT. Kaldu Sari Nabati Palembang, artinya Bila variabel Insentif $\left(X_{1}\right)$, Motivasi $\left(X_{2}\right)$ dan Lingkungan Kerja $\left(X_{3}\right)$ meningkat maka akan mengakibatkan meningkatnya Kinerja Pegawai $(Y)$, begitu pula sebaliknya, apabila variabel Insentif $\left(X_{1}\right)$, Motivasi $\left(X_{2}\right)$ dan Lingkungan Kerja $\left(X_{3}\right)$ menurun maka Kinerja Pegawai $(Y)$ juga akan menurun.

3. Bahwa antara variabel Insentif $\left(X_{1}\right)$, Motivasi $\left(X_{2}\right)$ dan Lingkungan Kerja $\left(X_{3}\right)$ mempunyai pengaruh terhadap Kinerja Pegawai (Y) PT. Kaldu Sari Nabati Palembang, terdapat korelasi 0,544 termasuk pada kategori tingkat pengaruh yang kuat karena setelah dibandingkan dengan nilai ( $r$ ) tabel dan nilai ( $r$ ) hitung.

4. Koefisien determinasi $\left(R^{2}\right)$ sebesar 0,296 nilai tersebut dapat ditafsirkan bahwa besarnya persentase pengaruh antara variabel Insentif $\left(X_{1}\right)$, Motivasi $\left(X_{2}\right)$ dan Lingkungan Kerja $\left(\mathrm{X}_{3}\right)$ mempunyai pengaruh secara bersama-sama terhadap variabel Kinerja Pegawai (Y) PT. Kaldu Sari Nabati Palembang. Dengan kata lain kontribusi efektif atau dapat dijelaskan oleh variabel Insentif $\left(X_{1}\right)$, Motivasi $\left(X_{2}\right)$ dan Lingkungan Kerja $\left(X_{3}\right)$ mempunyai pengaruh terhadap variabel Kinerja Pegawai (Y) PT. Kaldu Sari Nabati Palembang adalah sebesar 29,60\% sedangkan selebihnya 70,40\% dijelaskan / dipengaruhi oleh faktor-faktor yang tidak dimasukkan dalam penelitian ini.

\section{E. KESIMPULAN DAN SARAN}

1. Kesimpulan

Berdasarkan hasil penelitian dan intrepestasi yang telah dilakukan pada bab sebelumnya maka dapat ditarik beberapa kesimpulan antara lain :

a) Terdapat pengaruh variabel Insentif, Motivasi, dan Lingkungan Kerja secara bersama-sama atau simultan terhadap Kinerja Pegawai PT. Kaldu Sari Nabati Palembang. Dengan nilai sig F sebesar $0.000<\alpha(0,05)$. Korelasi $(R)$ sebesar 0,544 artinya pengaruh antara Insentif, Motivasi, dan Lingkungan Kerja menunjukkan korelasi yang signifikan dan bersikap positif (searah) terhadap Kinerja Pegawai PT. Kaldu Sari Nabati Palembang. Nilai koefisien determinasinya ( $R_{\text {square}}$ ) yaitu 0,296 atau $29,6 \%$. 
b) Secara Parsial, terdapat pengaruh variabel Insentif secara nyata terhadap variabel Kinerja Pegawai PT. Kaldu Sari Nabati Palembang. Ditunjukkan nilai sig t sebesar $0,002<\alpha(0,05)$.

c) Terdapat pengaruh variabel Motivasi secara nyata terhadap variabel Kinerja Pegawai PT. Kaldu Sari Nabati Palembang. Ditunjukkan nilai sig t sebesar $0,021<\alpha(0,05)$.

d) Terdapat pengaruh variabel Lingkungan Kerja secara nyata terhadap variabel Kinerja Pegawai PT. Kaldu Sari Nabati Palembang. Ditunjukkan nilai sig t sebesar $0,031<\alpha(0,05)$.

\section{Saran}

Berdasarkan kesimpulan dan hasil penelitian maka pada bagian berikut diberikan beberapa saran :

a) Bagi Pegawai PT.Kaldu Sari Nabati Palembang yaitu :

$>$ Untuk lebih mampu meningkatkan kinerjanya yang sudah baik sekarang ini, terutama indikator yang masih dapat ditingkatkan dan dikembangkan lagi karena skornya masih dibawah nilai rata-rata yaitu pada poin pertanyaan nomor 10 dan 12 dimana indikator tersebut adalah saya selalu mengutamakan ketelitian dalam bekerja sehingga hasilnya lebih baik dan saya memahami tugas saya sehingga tanpa menunggu perintah saya laksanakan dengan nilai total rata-rata 0.128 dan 0,275.

$>$ Untuk lebih mampu meningkatkan insentifnya yang sudah baik sekarang ini, terutama indikator yang masih dapat ditingkatkan dan dikembangkan lagi karena skornya masih dibawah nilai rata-rata yaitu pada poin pertanyaan nomor 2, 4, 8 dan 13 dimana indikator tersebut adalah bila dapat menyelesaikan tugas dengan baik saya mendapatkan imbalan, sistem insentif yang ada sudah sesuai dan adil, insentif diberikan sesuai dengan prestasi kerja pegawai dan saya sering mendapatkan hadiah uang tips atau sejenisnya dari pimpinan dengan nilai total rata-rata $-0,046,0,178$, 0,253 dan 0,196.

$>$ Untuk lebih mampu meningkatkan motivasinya yang sudah baik sekarang ini, terutama indikator yang masih dapat ditingkatkan dan dikembangkan lagi karena skornya masih dibawah nilai rata-rata yaitu pada poin pertanyaan nomor 3, 6 dan 12 dimana indikator tersebut adalah apabila saya dapat mencapai prestasi akan diberikan penghargaan dari kantor, tunjangan yang saya terima selama ini telah sesuai dengan jabatan beban tugas dan tanggungjawab dan selama ini saya merasa tercukupi akan fasilitas yang disediakan oleh perusahaan dengan nilai total rata-rata 0,076, 0,259 dan $-0,030$.

$>$ Untuk lebih mampu meningkatkan lingkungan kerjanya yang sudah baik sekarang ini, terutama indikator yang masih dapat ditingkatkan dan dikembangkan lagi karena skornya masih dibawah nilai rata-rata yaitu pada poin pertanyaan nomor 12 dan 14 dimana indikator tersebut adalah hubungan komunikasi antara atasan dan bawahan berjalan dengan baik dan menyenangkan serta selalu ada komunikasi dua arah antara bawahan dan atasan ditempat saya bekerja dengan nilai total rata-rata 0,105 dan 0,178 .

b) Bagi Pimpinan PT.Kaldu Sari Nabati Palembang agar lebih meningkatkan Insentif, Motivasi dan Lingkungan Kerja yang sudah terlaksana saat ini, hal ini 
bertujuan agar kinerja yang sudah baik saat ini mampu ditingkatkan lagi secara optimal terutama memperbaiki insentif pegawai PT. Kaldu Sari Nabati Palembang yang berdasarkan penelitian ini sangat signifikan sehingga secara parsial tidak mempengaruhi penurunan kinerja PT. Kaldu Sari Nabati Palembang.

c) Bagi peneliti lain, untuk menindaklanjuti lebih jauh hasil penelitian dengan mengembangkan variabel-variabel bebas yang lain misalnya Pengembangan Karir, Pendidikan dan Pelatihan, Budaya Organisasi sehingga dapat meningkatkan Kinerja PT.Kaldu Sari Nabati Palembang.

\section{DAFTAR PUSTAKA}

Alex S. Nitisemito, 2000. Manajemen Personalia, Ghalia Indonesia, Jakarta

Arifin, Zainal, 2012. Penelitian Pendidikan, PT Remaja Rosdakarya, Bandung.

As'ad, 2003. Seri Sumber Daya Manusia: Psikologi Industri. Edisi Keempat. Libery, Yogyakarta.

Danang, Sunyoto, 2012 . Manajemen Sumber Daya Manusia, CV.Masagung, Jakarta.

Dessler, Gary, 2007. Manajemen Personalia, Edisi Ketiga, Erlangga, Jakarta. \{ http://repository.usu.ac.id/bitstream/123456789/35686/2/Reference.pdf\}

Hasibuan, Malayu SP, 2000. Manajemen Sumber Daya Manusia, Bumi Aksara, Jakarta

Mangkunegara, A.P, 2005. Manajemen Sumber Daya Perusahaan, PT.Remaja Rosdakarya, Bandung. 